\title{
NARRATIVE REVIEW: OPTIMASI ETANOL SEBAGAI PELARUT SENYAWA FLAVONOID DAN FENOLIK
}

\section{Narrative Review: Optimization of Ethanol as a Solvent for Flavonoids and Phenolic Compounds}

\section{Ali Rakhman Hakim ${ }^{\text {* }}$}

Rina Saputri ${ }^{2}$

*IUniversitas Sari Mulia, Banjarmasin, Kalimantan Selatan, Indonesia

2Universitas Sari Mulia, Banjarmasin, Kalimantan Selatan, Indonesia

*email:

alirakhmanhakim@unism.ac.id

\begin{abstract}
Abstrak
Penggunaan etanol sebagai penyari senyawa metabolit sekunder sudah sangat luas. Etanol dapat melarutkan senyawa flavonoid dan senyawa fenolik dari tumbuhan. Untuk dapat memanfaatkan etanol sebagai pelarut secara maksimal harus memperhatikan faktor konsentrasi, suhu, waktu dan pemilihan metode ekstraksi. Studi ini menggunakan metode penelusuran artikel ilmiah dari database situs MDPI. Metode Ultrasound-Assisted Extraction (UAE) sangat cocok digunakan untuk optimasi etanol sebagai pelarut. Penggunaan etanol yang optimal berada pada rentang kosentrasi $50-80 \%$, kondisi suhu pada rentang $40-70^{\circ} \mathrm{C}$, dan waktu ekstraksi pada rentang 30 menit -24 jam.
\end{abstract}

\section{Kata Kunci: \\ Etanol \\ Fenolik \\ Flavonoid \\ Keywords: \\ Ethanol \\ Flavonoids \\ Phenolic}

\begin{abstract}
The use of ethanol as a solvent for secondary metabolite compounds is very widespread. Ethanol can dissolve flavonoid compounds and phenolic compounds from plants. To be able to utilize ethanol as a solvent is depend to some factors of concentration, temperature, time and selection of extraction methods. This study uses the method by searching scientific articles from the MDPI website database. The Ultrasound-Assisted Extraction (UAE) method is very suitable for the optimization of ethanol as a solvent. The optimal use of ethanol is in the concentration range of $50-80 \%$, temperature conditions in the range of $40-70^{\circ} \mathrm{C}$, and the extraction time is in the range of 30 minutes - 24 hours.
\end{abstract}

\section{(i) (9)}

\section{PEC}

Sejak lama tumbuhan telah digunakan secara empiris dan di olah secara tradisional untuk pengobatan. Saat ini pemanfaatan tumbuhan dalam pengembangan pengobatan sangat besar. Pemanfaatan tumbuhan semakin berkembang mengikuti berkembangnya ilmu pengetahuan dan teknologi pada bidang farmasi dan ilmu alam. Berubahnya pola pikir masyarakat pada obat herbal juga mempengaruhi pemanfaatan dari tumbuhan. Senyawa kimia pada tumbuhan menjadi komponen utama dalam pemanfaatan tumbuhan sebagai obat. Senyawa kimia alami yang digunakan untuk pengobatan tersebut merupakan kelompok dari senyawa metabolit sekunder dari tumbuhan. Senyawa metabolit sekunder tidak bersifat esensial bagi pertumbuhan tumbuhan tersebut. Pada umumnya senyawa metabolit sekunder memiliki peran utama untuk pertahanan diri terhadap organisme lain seperti serangga. Keberadaan metabolit sekunder terbatas pada tumbuhan asalnya atau suku dari tumbuhan tersebut. Diantara beberapa senyawa yang termasuk kelompok senyawa metabolit sekunder adalah senyawa flavonoid dan senyawa fenolik. Senyawa flavonoid tersebar hampir pada semua bagian tumbuhan pada akar daun bunga buah ataupun biji. Senyawa fenol tersebar luas pada tumbuhan, terutama dalam tumbuhan yang memiliki Senyawa aromatik yang memiliki karakteristik struktur benzen dan hidroksil.

Untuk mendapatkan senyawa flavonoid dan senyawa fenolik harus dilakukan dengan cara ekstraksi yaitu proses penyarian dari sumbernya. Secara konvensional, flavonoid dipisahkan dari matriks tumbuhan dengan metode yang membutuhkan pelarut dalam jumlah tinggi, 
waktu pemisahan yang lama, dan pemulihan yang rendah. Penyaringan senyawa flavonoid dan fenolik dari sumbernya dapat dioptimalkan dengan pemilihan pelarut yang sesuai. Pelarut memiliki peran penting dalam proses penyarian senyawa kimia. Sifat kepolaran dari pelarut sangat mempengaruhi dalam menyari senyawa target dari bahan bakunya. Telah banyak penelitian tentang cara atau metode mendapatkan senyawa flavonoid dan senyawa fenolik menggunakan pelarut etanol dengan konsentrasi yang berbeda-beda. Penggunaan pelarut etanol dapat menjadi optimal jika faktor konsentrasi, suhu, waktu dan pemilihan metode ekstraksi sesuai. Empat faktor ini tidak bisa disamaratakan dalam setiap proses ekstraksi karena masing-masing bagian tumbuhan memiliki karakteristik yang berbeda-beda.

\section{METODOLOGI}

Peninjauan literatur artikel dilakukan melalui penelusuran Internet dengan mengakses database dari situs MDPI. Penelusuran artikel disaring menggunakan kata kunci extraction, ethanol, flavonoids, dan phenolic. Artikel-artikel yang dianggap memenuhi kriteria akan dijadikan sumber untuk ulasan lebih lanjut.

\section{HASIL DAN PEMBAHASAN}

\section{Etanol}

Etanol merupakan pelarut organik yang sering digunakan untuk proses ekstraksi dan sudah sangat banyak laporan atau artikel penelitian dari penggunaan etanol. Beberapa alasan penggunaan etanol yang sangat luas antara lain karena etanol relatif tidak toksik dibandingkan dengan aseton dan metanol, biaya murah, dapat digunakan pada berbagai metode ekstraksi, serta aman untuk ekstrak yang akan dijadikan obat-obatan dan makanan. Alasan lainnya adalah karena etanol merupakan pelarut yang mudah didapatkan, efisien, aman untuk lingkungan, dan memiliki tingkat ekstraksi yang tinggi (Chen et al, 2020; Fan et al, 2020; dan Jiménez-Moreno et al, 2019).

Konsentrasi dari etanol sangat mempengaruhi hasil dari ekstrak yang didapatkan. Penggunaan Etanol sebagai pelarut dapat dikombinasikan dengan air yang dinyatakan dengan satuan persen (\%) dan sekaligus dapat dijadikan parameter dalam proses ekstraksi. Kombinasi etanol-air menghasilkan perbedaan konsentrasi polaritas dari pelarut ekstraksi. Konsentrasi dari etanol sangat menentukan kekuatan hidrofobik pada proses pelarutan serta kekuatan ikatan-ikatan hidrogen atau gaya van der Waals dari komponen target dalam proses pelarutan dan penyarian dari komponen target. Mengacu kepada teori kesamaan dan kemampuan saling bercampur, semakin mirip polaritas pelarut dengan zat terlarut, semakin cepat pelarutan zat terlarut dari sel tumbuhan. Meningkatnya konsentrasi etanol dapat meningkatkan laju disolusi dan ekstraksi. Ketika konsentrasi etanol lebih besar dari $70 \%$, tingkat ekstraksi komponen target sedikit menurun, kemungkinan karena denaturasi protein meningkatkan resistensi difusi pada konsentrasi etanol yang lebih tinggi (Fan et al, 2020 dan Thoo et al, 20l3).

2. Metode optimasi etanol sebagai pelarut

Tabel I. Hasil optimal berdasarkan konsentrasi etanol, suhu, dan waktu eksraksi

\begin{tabular}{|c|c|c|c|c|c|c|c|}
\hline $\begin{array}{l}\mathbf{N} \\
\mathbf{0}\end{array}$ & $\begin{array}{c}\text { Pela } \\
\text { rut }\end{array}$ & $\begin{array}{l}\text { Su } \\
\text { hu }\end{array}$ & $\begin{array}{l}\text { Wa } \\
\text { ktu }\end{array}$ & $\begin{array}{l}\text { Bagi } \\
\text { an } \\
\text { Simp } \\
\text { lisia }\end{array}$ & $\begin{array}{c}\text { Kada } \\
\mathbf{r} \\
\text { Flavo } \\
\text { noid } \\
\text { Total }\end{array}$ & $\begin{array}{c}\text { Kad } \\
\text { ar } \\
\text { Fen } \\
\text { olik } \\
\text { Tot } \\
\text { al }\end{array}$ & $\begin{array}{c}\text { Literat } \\
\text { ur }\end{array}$ \\
\hline I & $\begin{array}{l}\text { Etan } \\
\text { ol } \\
70 \%\end{array}$ & $\begin{array}{l}61^{\circ} \\
C\end{array}$ & $\begin{array}{l}30 \\
\text { men } \\
\text { it }\end{array}$ & Bunga & $\begin{array}{l}26.426 \\
0 \%\end{array}$ & - & Fan et al \\
\hline 2 & $\begin{array}{l}\text { Etan } \\
\text { ol } \\
50 \%\end{array}$ & $\begin{array}{l}45^{\circ} \\
C\end{array}$ & $\begin{array}{l}60 \\
\text { men } \\
\text { it }\end{array}$ & Beras & $\begin{array}{l}156.20 \\
\mathrm{mg} / \mathrm{I0} \\
0 \mathrm{~g}\end{array}$ & $\begin{array}{l}288 . \\
40 \\
\mathrm{mg} / \mathrm{I} \\
00 \mathrm{~g}\end{array}$ & $\begin{array}{l}\text { Ghasem } \\
\text { zadeh et } \\
\text { al }\end{array}$ \\
\hline 3 & $\begin{array}{l}\text { Etan } \\
\text { ol } \\
50 \%\end{array}$ & $\begin{array}{l}40^{\circ} \\
\mathrm{C}\end{array}$ & $\begin{array}{l}24 \\
\text { jam }\end{array}$ & $\begin{array}{l}\text { Batan } \\
g \\
\text { buah }\end{array}$ & $\begin{array}{l}23 \pm \\
\mathrm{II} \\
\mu \mathrm{g} / \mathrm{g}\end{array}$ & $\begin{array}{l}106 \\
\pm 47 \\
\mu g / g\end{array}$ & $\begin{array}{l}\text { Jiménez } \\
\text { - } \\
\text { Moreno } \\
\text { et al }\end{array}$ \\
\hline 4 & $\begin{array}{l}\text { Etan } \\
\text { ol } \\
80 \%\end{array}$ & $\begin{array}{l}70^{\circ} \\
\mathrm{C}\end{array}$ & $\begin{array}{l}45 \\
\text { men } \\
\text { it }\end{array}$ & $\begin{array}{l}\text { Biji } \\
\text { buah }\end{array}$ & $\begin{array}{l}9.805 \\
\pm 0.69 \\
\mathrm{mg} / \mathrm{g}\end{array}$ & $\begin{array}{l}128 . \\
58 \pm \\
1.61 \\
\mathrm{mg} / \mathrm{g}\end{array}$ & $\begin{array}{l}\text { Zulkifli } \\
\text { et al }\end{array}$ \\
\hline 5 & $\begin{array}{l}\text { Etan } \\
\text { ol } \\
75 \%\end{array}$ & $\begin{array}{l}57^{\circ} \\
C\end{array}$ & $\begin{array}{l}40 \\
\text { men } \\
\text { it }\end{array}$ & Buah & $\begin{array}{l}552.53 \\
\pm \\
34.16\end{array}$ & $\begin{array}{l}881 . \\
57 \pm \\
17.7\end{array}$ & $\begin{array}{l}\text { Thoo et } \\
\text { al }\end{array}$ \\
\hline
\end{tabular}


Ali Rakhman Hakim, Rina Saputri. 2020. Narrative Review: Optimization of Ethanol as a Solvent for Flavonoids and Phenolic Compounds

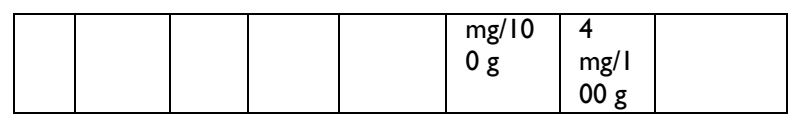

Penggunaan pelarut etanol dalam upaya mendapatkan kadar senyawa flavonoid dan senyawa fenolik yang optimal sangat tergantung kepada faktor konsentrasi, suhu, waktu dan pemilihan metode ekstraksi. Salah satu metode eksraksi yang sering digunakan untuk optimasi adalah Ultrasound-Assisted Extraction (UAE). Parameter yang digunakan saat optimasi menggunakan UAE adalah frekuensi ultrasonik, suhu, konsentrasi pelarut, dan waktu. Ultrasonik pada beberapa penelitian telah diakui sebagai metode yang andal dan cepat untuk mengekstraksi berbagai senyawa dari matriks alami (Sambou et al, 2020). Ultrasonik, sebagai salah satu jenis gelombang mekanis, menyebabkan kavitasi, memecah sitoderm sel tumbuhan selama proses propagasi di seluruh medium cair, serta amplitudo ultrasonik dan intensitas ultrasonik berkaitan erat dengan kekuatan iradiasi ultrasonik, yang berkontribusi pada hasil beragam (Wei et al, 2020).

Berdasarkan tabel I, dapat dilihat beberapa data hasil optimasi dari etanol dalam upaya mendapatkan kadar flavonoid total dan kadar senyawa fenolik total. Berdasarkan tabel I, penggunaan etanol berada pada rentang kosentrasi $50-80 \%$, kondisi temperatur pada rentang $40-70^{\circ} \mathrm{C}$, dan waktu ekstraksi pada rentang 30 menit - 24 jam. Berdasarkan data ini untuk mendapatkan senyawa flavonoid dan senyawa fenolik dalam kadar yang tinggi dapat menggunakan pelarut etanol dengan konsentrasi tidak lebih dari $80 \%$.

Contoh dari hasil penelitian Ghasemzadeh et al menunjukkan campuran etanol-air $(50: 50 \mathrm{v} / \mathrm{v})$ pada ekstraksi dengan metode UAE pada suhu $45^{\circ} \mathrm{C}$ selama 60 menit lebih efektif dalam ekstraksi senyawa fenolik dan dapat memberikan tekanan menarik senyawa fenolik yang lebih besar pada jaringan tumbuhan. Jika kita mempertimbangkan viskositas cairan, cairan dengan viskositas rendah lebih efektif karena energi ultrasonik dapat lebih mudah mengatasi kekuatan molekul cairan viskositas rendah. Selain itu, cairan dengan viskositas rendah juga dapat dengan mudah menembus jaringan tumbuhan karena kepadatannya yang rendah dan difusivitasnya yang tinggi.

Pencarian senyawa flavonoid dan senyawa fenolik dari tumbuhan dapat dikatakan penting. Hal ini karena senyawa flavonoid memiliki potensi sebagai senyawa dasar untuk penelitian ke arah farmakologi. Kandungan flavonoid dalam tumbuhan sangat bervariasi. Variasi dari kandungan flavonoid dalam tumbuhan dapat terjadi karena beberapa faktor seperti genotipe, kondisi lingkungan dalam proses pertumbuhan, tahap pertumbuhan, penanganan pascapanen, dan kondisi penyimpanan. Faktor-faktor ini dapat mempengaruhi konsentrasi flavonoid total dan komposisi flavonoid dalam tumbuhan.

Beberapa penelitian menyatakan bahwa akumulasi flavonoid di setiap bagian tumbuhan dapat berbedabeda, seperti daun, bunga, dan buah adalah hasil dari biosintesis in situ dan proses translokasi dari daun ke organ lain. Kandungan flavonoid dalam organ tumbuhan yang berbeda dapat dipengaruhi oleh hubungan sintesis atau transportasi dalam jaringan dan variasi senyawa dapat terjadi selama pengembangan organ tumbuhan (Rojsanga et al, 2020).

Semakin tinggi kadar senyawa fenolik yang ada dalam tumbuhan maka akan memiliki fungsi antioksidan yang tinggi (Ghasemzadeh et al, 2015 dan Thoo et al, 20l3). Ketika total konten polifenol meningkat, aktivitas fisiologis seperti antioksidan juga meningkat (Kwon et al, 2020).

\section{KESIMPULAN}

Pelarut etanol sangat baik untuk mendapatkan senyawa flavonoid dan fenolik. Pelarut etanol dapat di optimasi perannya sebagai pelarut senyawa flavonoid dan senyawa fenolik dengan menggunakan metode Ultrasound-Assisted Extraction (UAE) dengan 
memperhatikan faktor konsentrasi etanol, suhu, dan waktu.

\section{UCAPAN TERIMA KASIH}

Ucapan terima kasih kepada Lembaga Penelitian dan Pengabdian Masyarakat Universitas Sari Mulia yang mendukung penuh kegiatan penelitian ini.

\section{REFERENSI}

I. Chen, H., Xiao, H., \& Pang, J. (2020). Parameter Optimization and Potential Bioactivity Evaluation of a Betulin Extract from White Birch Bark. Plants, 9(3), 392.

2. Fan, S., Yang, G., Zhang, J., Li, J., \& Bai, B. (2020). Optimization of Ultrasound-Assisted Extraction Using Response Surface Methodology for Simultaneous Quantitation of Six Flavonoids in Flos Sophorae Immaturus and Antioxidant Activity. Molecules, 25(8), 1767.

3. Jiménez-Moreno, N., Volpe, F., Moler, J. A., Esparza, I., \& Ancín-Azpilicueta, C. (2019). Impact of Extraction Conditions on the Phenolic Composition and Antioxidant Capacity of Grape Stem Extracts. Antioxidants, 8(12), 597.

4. Thoo, Y. Y., Ho, S. K., Abas, F., Lai, O. M., Ho, C. W., \& Tan, C. P. (20I3). Optimal binary solvent extraction system for phenolic antioxidants from mengkudu (Morinda citrifolia) fruit. Molecules, 18(6), 7004-7022.

5. Sambou, M., Jean-François, J., Ndongou Moutombi, F.I., Doiron, I.A., Hébert, M., loy, A.P., Mai-Thi, N.N., Barnett, D.A., Surette, M.E., Boudreau, L.H. and Touaibia, M. (2020). Extraction, Antioxidant Capacity, 5-Lipoxygenase Inhibition, and Phytochemical Composition of Propolis from Eastern Canada. Molecules, 25(I0), p.2397.

6. Wei, M., Zhao, R., Peng, X., Feng, C., Gu, H., \& Yang, L. (2020). Ultrasound-Assisted Extraction of Taxifolin, Diosmin, and Quercetin from Abies nephrolepis (Trautv.) Maxim: Kinetic and Thermodynamic Characteristics. Molecules, 25(6), I40I.

7. Ghasemzadeh, A., Jaafar, H. Z., Juraimi, A. S., \& Tayebi-Meigooni, A. (20I5). Comparative evaluation of different extraction techniques and solvents for the assay of phytochemicals and antioxidant activity of hashemi rice bran. Molecules, 20(6), 10822-10838.

8. Rojsanga, P., Bunsupa, S., \& Sithisarn, P. (2020). Flavones Contents in Extracts from Oroxylum indicum Seeds and Plant Tissue Cultures. Molecules, 25(7), 1545.

9. Kwon, H.Y., Choi, S.I., Park, H.I., Choi, S.H., Sim, W.S., Yeo, J.H., Cho, J.H. and Lee, O.H. (2020). Comparative Analysis of the Nutritional Components and Antioxidant Activities of Different Brassica Juncea Cultivars. Foods, 9(6), p.840.

10. Zulkifli, S. A., Abd Gani, S. S., Zaidan, U. H., \& Halmi, M. I. E. (2020). Optimization of total phenolic and flavonoid contents of defatted pitaya (Hylocereus polyrhizus) seed extract and its antioxidant properties. Molecules, 25(4), 787. 